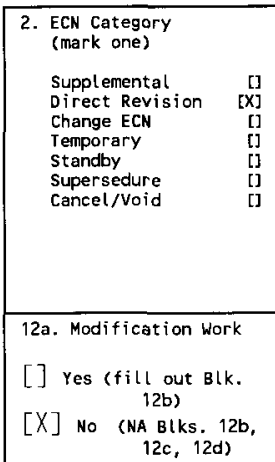

13a. Description of Change Complete revision.
3. Originator's Name, Organization, MSIN, and Telephone No.

Dave $L$. Banning, Technical

Basis and Planning, R2-12, 3722728

6. Project Title/No./Work Order No.

Data Quality Objectives for TwRS Privatization Phase I

9. Document Numbers Changed by this ECN (includes sheet no. and rev.) HNF-1796, Rev. 1
Page i of 2

5. Date

$03 / 01 / 99$

[] Yes $[X]$ No

8. Approval Designator

7. Bldg./Sys./Fac. No. $N / A$

10. Related ECN No(s).

11. Related PO No. ECN-644463

$\mathrm{N} / \mathrm{A}$

12b. Work Package $12 \mathrm{c}$. Modification Work Complete No.

N/A

$N / A$

12d. Restored to Original Condition (Temp. or Standby ECN only) N/A

Design Authority/Cog. Engineer Signature \& Date Signature \&ate

[X] No

13b. Design Basel ine Document?

[] Yes

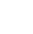




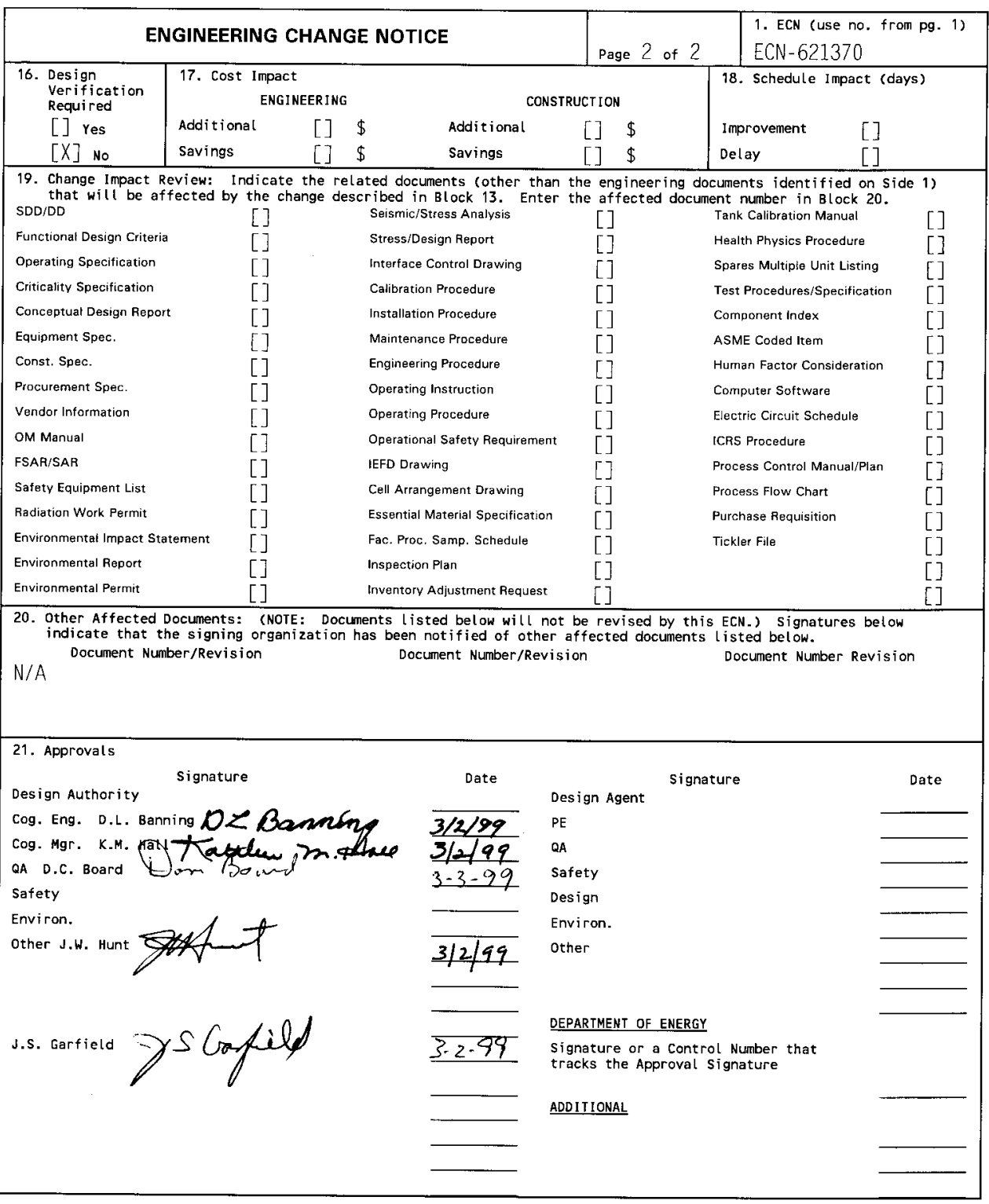




\title{
Data Quality Objectives for TWRS Privatization Phase I: Confirm Tank $T$ is an Appropriate Feed Source for Low-Activity Waste Feed Batch $\mathbf{X}$
}

\author{
D. M. Nguyen
}

Lockheed Martin Hanford. Corp. . Richland, WA 99352

U.S. Department of Energy Contract DE-AC06-96RL13200

\author{
EDT/ECN: $\quad$ ECN-621370 UC: 2070 \\ Org Code: $74 \mathrm{~B} 10$ \\ B\&R Code: EW 3120074 Total Pages: 30

Key Words: Data Quality Objective, DQO. TWRS, Privatization, Phase I, Tank T. Feed Source, Low-Actvity Waste Feed. Low-Activity. Waste Feed, Batch $x$

Abstract: $N / A$

TRADEMARK DISCLAIMER. Reference herein to any specific cormercial product, process, or service by trade name, trademark, manufacturer, or otherwise, does not necessarily constitute or imply its endorsement, recommendation, or favoring by the United States Government or any agency thereof or its contractors or subcontractors.

Printed in the United States of America. To obtain copies of this document, contact: Document Control Services, P.0. Box 950, Mailstop H6-08, Richland WA 99352, Phone (509) 372-2420; Fax (509) 376-4989.
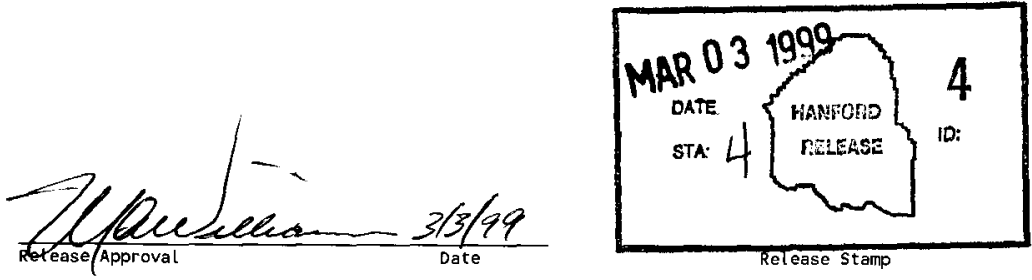

Approved for Public Release 


\section{RECORD OF REVISION}

(1) Document Number

HNF-1796

(2) Title

Data Quality Objectives for TWRS Privatization Phase 1: Confirm Tank $T$ is an Appropriate Feed Source for Low-Activity Waste Feed Batch $X$

CHANGE COHTROL RECORD

\begin{tabular}{|c|c|c|c|}
\hline \multirow{2}{*}{ Revision } & \multirow{2}{*}{ (4) Description of Change - Replace, Add, and Delete Pages } & \multicolumn{2}{|c|}{ Authorized for Release } \\
\hline & & (5) Cog. Engr. & (6) Cog. Ngr, Date \\
\hline 0 & (7) Initial release $1 / 20 / 98$, EOT 622701 . & P. J. Certa & J. S. Garfield \\
\hline RS & 7/1/98 Direct revision per ECN-644463. & $\begin{array}{l}\text { P. 3. Certa } \\
\text { Pfdcets }\end{array}$ & 3. S. Gayfiygld \\
\hline RS & Incorporate per Esn-621370. & D.L. Banning & K.m. Hall \\
\hline & & DADenning & Sachlea \\
\hline
\end{tabular}


HNF-1796

Revision 2

\title{
DATA QUALITY OBJECTIVES FOR TWRS PRIVATIZATION PHASE 1: CONFIRM TANK T IS AN APPROPRIATE FEED SOURCE FOR LOW-ACTIVITY WASTE FEED BATCH $X$
}

\author{
D. M. Nguyen \\ Lockheed Martin Hanford Corporation
}

Date Published

March 1999

Prepared for the U. S. Department of Energy

Assistant Secretary for Environmental Management

Project Hanford Management Contractor for the

U.S. Department of Energy urder Contract DE-AC06-96RL13200

Approved for public release; distribution is unlimited 
This page intentionally left blank 


\section{TABLE OF CONTENTS}

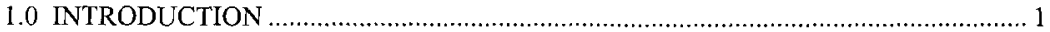

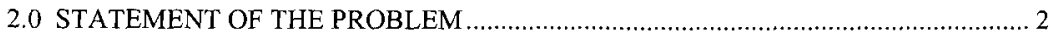

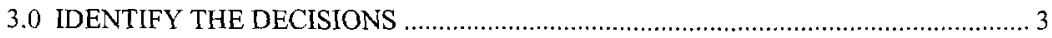

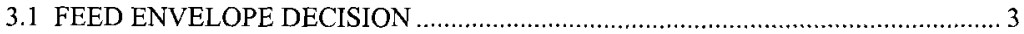

3.2 WASTE TRANSFER DECISION

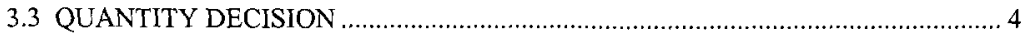

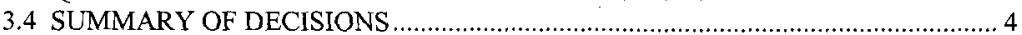

4.0 IDENTIFY THE INPUTS TO THE DECISIONS ….......................................... 5

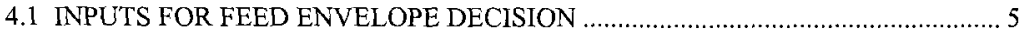

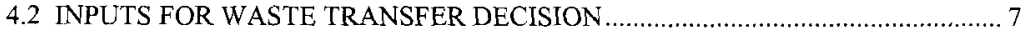

4.3 INPUTS FOR QUANTITY DECISION …....................................................... 9

4.4. ANALYTICAL METHODS AND QUALITY CONTROL REQUIREMENTS ....... 10

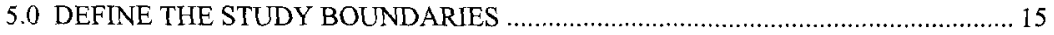

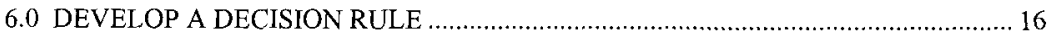

7.0 SPECIFY TOLERABLE LIMITS ON DECISION ERRORS ................................... 17

7.1 ACCEPTABLE ERRORS FOR FEED ENVELOPE DECISION …........................ 17

7.2 ACCEPTABLE ERROR LIMITS FOR WASTE TRANSFER DECISION ............. 18

8.0 OPTIMIZE THE DESIGN FOR DATA COLLECTION ....................................... 20

8.1 OPTIMIZE SAMPLING DESIGN FOR FEED ENVELOPE DECISION ................20

8.2 OPTIMIZE SAMPLING DESIGN FOR THE WASTE TRANSFER DECISION .... 21

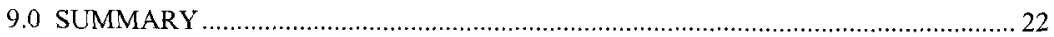

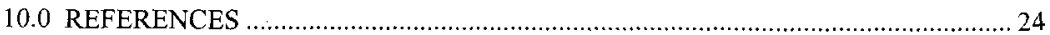




\section{LIST OF TABLES}

TABLE 4.1 LOW-ACTIVITY WASTE FEED CHEMICAL COMPOSITION MAXIMUM LIMITS, SOLUBLE FRACTION ONLY ............................................... 6

TABLE 4.2 LOW-ACTIVITY WASTE FEED RADIONUCLIDE CONTENT MAXIMUM LIMITS, SOLUBLE FRACTION ONLY ................................................. 6

TABLE 4.3 INSOLUBLE COMPONENTS REQUIRING CHARACTERIZATION ...........7

TABLE 4.4 APPLICABLE TANK FARM OPERATING SPECIFICATIONS..................... 7

TABLE 4.5 WASTE TRANSFER PROPERTIES AND ASSOCIATED LIMITS ................ 8

TABLE 4.6 REQUIRED ANALYTES AND QUALITY CONTROL REQUIREMENTS . 10

TABLE 4.7 MINIMUM REPORTABLE QUANTITIES FOR LAW FEED, SOLUBLE FRACTION ONLY (2 SHEETS) .......................................................... 12

TABLE 4.8 MINIMUM REPORTABLE QUANTITIES FOR LAW FEED ANALYTES NOT SPECIFIED IN FEED ENVELOPE, SOLUBLE FRACTION ONLY.... 14 TABLE 9.1 OVERALL DATA COLLECTION SCHEME ................................................ 23

\section{LIST OF TERMS}

$\mathrm{Bq}$
$\mathrm{Ci} / \mathrm{L}$
DOE
DOE-RL
DQO
EQL
HLW
ICD
LAW
$\mathrm{M}$
MDA
MRQ
OSD
PHMC
PMBS
PUREX
QC
SAP
TRU
TWRS
TWRSO\&UP
${ }^{\circ} \mathrm{C}$
$\mu \mathrm{g} / \mathrm{mL}$
$\mu \mathrm{Ci} / \mathrm{mL}$
${ }^{\%} \%$

Becquerel curies per liter the U.S. Department of Energy U.S. Department of Energy, Richland Operations Office data quality objective estimation quantitation limits high-level waste interface control document low-activity waste molar (moles per liter) minimum detectable activity minimum reportable quantity Operating Specification Document Project Hanford Management Contract(or) project master baseline schedule Plutonium-Uranium Extraction Plant quality control sampling and analysis plan transuranic Tank Waste Remediation System Tank Waste Remediation System Operation and Utilization Plan degrees Celsius micrograms per milliliter microcuries per milliliter percent 
HNF-1796 Rev. 2

\section{DATA QUALITY OBJECTIVES FOR TWRS PRIVATIZATION PHASE 1: CONFIRM TANK T IS AN APPROPRIATE FEED SOURCE FOR LOW-ACTIVITY WASTE FEED BATCH $X$}

\subsection{INTRODUCTION}

The U.S. Department of Energy, Richland Operations Office (DOE-RL) has initiated Phase 1 of a two-phase privatization strategy for treatment and immobilization of low-activity waste (LAW) currently being managed by the Hanford Tank Waste Remediation System (TWRS) Project. In this strategy, DOE will purchase services from a contractor-owned and operated facility under a fixed price. The Phase 1 TWRS privatization contract requires that the Project Hanford Management Contract (PHMC) contractors, on behalf of DOE, deliver LAW feed in specified quantities and composition to the Privatization Contractor in a timely manner (DOE-RL 1996). Additional requirements are imposed by the interface control document (ICD-19) for LAW feed (PHMC 1997).

In response to these requirements, the Tank Waste Remediation System Operation and Utilization Plan (TWRSO\&UP) (Kirkbride et al. 1997) was prepared by the PHMC. The TWRSO\&UP, as updated by the Readiness-To-Proceed deliverable (Payne et al. 1998), establishes the baseline operating scenario for the delivery of LAW feed to the Privatization Contractor. The scenario specifies tanks from which LAW will be provided for each feed batch, the operational activities needed to prepare and deliver each batch, and the timing of these activities. The operating scenario was developed based on current knowledge of waste composition and chemistry, waste transfer methods, and operating constraints, such as tank farm logistics and availability of tank space.

A project master baseline schedule (PMBS) has been developed to implement the operating scenario. The PMBS also includes activities aimed at reducing programmatic risks. One of the activities, "Confirm Plans and Requirements," was identified to verify the basis used to develop the scenario. Additional data on waste quantity, physical and chemical characteristics, and transfer properties will be needed to support this activity.

This document describes the data quality objective (DQO) process undertaken to assure appropriate data will be collected to support the activity, "Confirm Tank Plans and Requirements." The DQO process was implemented in accordance with the TWRS DQO process (Banning 1997) with some modifications to accommodate project or tank-specific requirements and constraints. 


\subsection{STATEMENT OF THE PROBLEM}

An initial screening of tank waste composition has been conducted to identify potential waste feed for the Phase I TWRS Privatization Contractor. Tanks 241-AN-102, 241-AN-103, 241-AN-104, 241-AN-105, 241-AN-107, 241-AW-101, and 241-SY-101 currently contain waste that is targeted as candidate LAW feed. In addition, high-level waste (HLW) feed (from tanks 241-AZ-101, 241-AZ-102, 241-C-102, 241-C-104, and 241-C-106) will be transferred to a staging tank as slurry. The liquid fraction of HLW slurry, after being pretreated to remove Cesium-137, is considered LAW. Data requirements for HLW liquid streams are addressed in this document. Requirements for HLW solids are addressed in the Data Quality Objectives for TWRS Privatization Phase I: Confirm Tank T is An Appropriate Feed Source for High-Level Waste Feed Batch X (Nguyen 1999).

The tank screening was based on current best-basis estimates, process test data, process simulation, and project schedules. To minimize programmatic risks, additional data are needed to supplement existing knowledge regarding waste characteristics and behavior. The data will be used to demonstrate that Privatization Contract limits, waste transfer, and contract order quantity requirements can be satisfied. In other words, sufficient data must be available to prevent an occurrence of the following potential "problems":

1. The characteristics of a delivered feed batch exceed the limits required by the TWRS Privatization Contract (i.e., the feed envelope).

2. The characteristics and behavior of the LAW are such that the PHMC cannot transfer the waste, when needed, from a candidate waste tank to a feed staging tank.

3. The quantity (units) of LAW transferred to a feed tank is significantly different from that estimated for a tank or feed batch.

Waste transfer and contract order quantity requirements for HLW are addressed in Nguyen (1999). Hence, only feed envelope DQOs, as described in this document, are applicable to the liquid fraction of HLW feed slurry. 
HNF-1796 Rev. 2

\subsection{IDENTIFY THE DECISIONS}

To avoid the "problems" discussed in the previous section, the following principal study questions must be answered:

1. Do the LAW feed characteristics exceed the envelope limits?

2. Do the physical and rheological characteristics of the LAW exceed the waste transfer criteria?

3. Is the quantity of waste significantly different from that estimated for the tank or feed batch?

In combination, the answers to these questions will resolve the overall primary question:

Is the waste in Tank $T$ (i.e., a candidate LAW feed tank) appropriate for use as source material for $L A W$ feed batch $X$ ?

\subsection{FEED ENVELOPE DECISION}

The alternative actions that could result from resolution of the principal study question regarding feed envelope requirements include:

1. All LAW feed characteristics are within the envelope limits. No further action is needed.

2. One or more of the LAW feed characteristics are outside the envelope limits. Another waste could be selected as candidate feed. Alternatively, DOE could negotiate with the Privatization Contractor to accept out-of-specification waste feed or modify the envelope.

\subsection{WASTE TRANSFER DECISION}

The alternative actions that could result from resolution of the principal study question regarding waste transfer requirements include:

1. All physical and rheological characteristics of the waste meet the established criteria for waste transfer. No further action is needed.

2. One or more physical or rheological characteristics of the waste exceed the established criteria for waste transfer. The waste properties could be adjusted, the waste transfer criteria could be modified, or another waste could be selected. 


\section{HNF-1796 Rev. 2}

\subsection{QUANTITY DECISION}

The alternative actions that could result from resolution of the principal study question regarding feed quantity requirement include:

1. The quantity of LAW in Tank T is approximately the same as previous estimate. No further action is needed.

2. The quantity of LAW in Tank $T$ is significantly different from previous estimate. $A$ quantity much lower than expected could result in selection of another candidate waste tank or another tank could be selected to provide additional feed.

Alternatively, DOE could negotiate new quantity requirements with the Privatization Contractor. A higher than anticipated quantity of waste in a tank is not expected to result in a feed delivery problem. In this case, a smaller batch would be transferred to the staging tank.

\subsection{SUMMARY OF DECISIONS}

Based on the study questions and the associated alternative actions, the following decision statements are established:

1. Determine whether or not chemical and radiological characteristics of the LAW feed exceed the envelope limits and, therefore, require actions to accept out-ofspecification feed, modify the envelope, or select another candidate waste.

2. Determine whether or not physical and rheological properties of the waste exceed established waste transfer criteria and, therefore, require actions to adjust the waste properties, modify the waste transfer criteria, or select another candidate waste.

3. Determine whether or not the quantity of LAW is significantly less than previous estimate and, therefore, could require actions to select another candidate waste or negotiate new requirements. 


\subsection{IDENTIFY THE INPUTS TO THE DECISIONS}

The information inputs required to resolve the decision statements are divided into three sections for clarification: Inputs for Feed Envelope Decision, for Waste Transfer Decision, and for Quantity Decision (Sections 4.1, 4.2, and 4.3). The bases for selecting the required inputs are also discussed in these sections. The analytical methods and quality control requirements for these inputs are provided in Section 4.4.

\subsection{INPUTS FOR FEED ENVELOPE DECISION}

The TWRS Privatization Contract divides the LAW into three categories and specifies concentration limits for each type. These sets of limits are known as Envelopes A, B, and C. The limits are described in terms of moles or Becquerels $(\mathrm{Bq})$ of components per mole of sodium in the soluble fraction of the waste. The feed envelope limits are shown in Tables 4.1 and 4.2 of this DQO. Characterization of certain chemicals and radionuclides in the insoluble fraction also is required but no limits are specified for these species (see Table 4.3). Other feed delivery requirements include:

- The feed shall not contain a visible organic phase,

- The maximum ${ }^{137} \mathrm{Cs}$ concentration in the transferred feed shall be less than $6 \mathrm{Ci} / \mathrm{L}$ (This requirement is not applicable to HLW liquid),

- The waste feed shall be delivered with a sodium concentration between $3 \mathrm{M}$ and $10 \underline{\mathrm{M}}$

- The waste feed may contain up to 2 weight percent solids on dry basis (This requirement is not applicable to HLW liquid), and

- The waste feed shall meet limits in the Tank Farm Operating Specification Document (OSD) T-151-0007 (PHMC 1998) except for free hydroxide. The applicable specifications are shown in Table 4.4. Limits are specified by the OSD for nitrate $\left(\mathrm{NO}_{3}\right)$, nitrite $\left(\mathrm{NO}_{2}\right)$, and hydroxide $(\mathrm{OH})$. Nitrate and nitrite concentrations in the waste will be determined as part of Tables 4.1 and 4.2. Hydroxide limits are specified in terms of hydroxide alone or in combination with nitrate and/or nitrite. Although satisfying the OSD limit for hydroxide is not required by the Privatization Contract, hydroxide concentration data will be needed to demonstrate compliance with other OSD requirements (i.e., hydroxide in combination with nitrate and nitrite). 
TABLE 4.1. LOW-ACTIVITY WASTE FEED CHEMICAL COMPOSITION

MAXIMUM LIMITS, SOLUBLE FRACTION ONLY (moles of component per mole of sodium)

\begin{tabular}{|c|c|c|c|}
\hline $\begin{array}{c}\text { Chemical } \\
\text { Component }\end{array}$ & Envelope A & Envelope B & Envelope C \\
\hline $\mathrm{Al}$ & $2.5 \mathrm{E}-01$ & $2.5 \mathrm{E}-01$ & $2.5 \mathrm{E}-01$ \\
\hline $\mathrm{Ba}$ & $1.0 \mathrm{E}-04$ & $1.0 \mathrm{E}-04$ & $1.0 \mathrm{E}-04$ \\
\hline $\mathrm{Ca}$ & $4.0 \mathrm{E}-02$ & $4.0 \mathrm{E}-02$ & $4.0 \mathrm{E}-02$ \\
\hline $\mathrm{Cd}$ & $4.0 \mathrm{E}-03$ & $4.0 \mathrm{E}-03$ & $4.0 \mathrm{E}-03$ \\
\hline $\mathrm{Cl}$ & $3.7 \mathrm{E}-02$ & $8.9 \mathrm{E}-02$ & $3.7 \mathrm{E}-02$ \\
\hline $\mathrm{Cr}$ & $6.9 \mathrm{E}-03$ & $2.0 \mathrm{E}-02$ & $6.9 \mathrm{E}-03$ \\
\hline $\mathrm{F}$ & $9.1 \mathrm{E}-02$ & $2.0 \mathrm{E}-01$ & $9.1 \mathrm{E}-02$ \\
\hline $\mathrm{Fe}$ & $1.0 \mathrm{E}-02$ & $1.0 \mathrm{E}-02$ & $1.0 \mathrm{E}-02$ \\
\hline $\mathrm{Hg}$ & $1.4 \mathrm{E}-05$ & $1.4 \mathrm{E}-05$ & $1.4 \mathrm{E}-05$ \\
\hline $\mathrm{K}$ & $1.8 \mathrm{E}-01$ & $1.8 \mathrm{E}-01$ & $1.8 \mathrm{E}-01$ \\
\hline $\mathrm{La}$ & $8.3 \mathrm{E}-05$ & $8.3 \mathrm{E}-05$ & $8.3 \mathrm{E}-05$ \\
\hline $\mathrm{Ni}^{-}$ & $3.0 \mathrm{E}-03$ & $3.0 \mathrm{E}-03$ & $3.0 \mathrm{E}-03$ \\
\hline $\mathrm{NO}_{2}^{-}$ & $3.8 \mathrm{E}-01$ & $3.8 \mathrm{E}-01$ & $3.8 \mathrm{E}-01$ \\
\hline $\mathrm{NO}_{3}^{-}$ & $8.0 \mathrm{E}-01$ & $8.0 \mathrm{E}-01$ & $8.0 \mathrm{E}-01$ \\
\hline $\mathrm{Pb}^{-}$ & $6.8 \mathrm{E}-04$ & $6.8 \mathrm{E}-04$ & $6.8 \mathrm{E}-04$ \\
\hline $\mathrm{PO}_{4}^{-2}$ & $3.8 \mathrm{E}-02$ & $1.3 \mathrm{E}-01$ & $3.8 \mathrm{E}-02$ \\
\hline $\mathrm{SO}_{4}^{-2}$ & $1.0 \mathrm{E}-02$ & $7.0 \mathrm{E}-02$ & $2.0 \mathrm{E}-02$ \\
\hline $\mathrm{TIC}^{-1}$ & $3.0 \mathrm{E}-01$ & $3.0 \mathrm{E}-01$ & $3.0 \mathrm{E}-01$ \\
\hline $\mathrm{TOC}^{2}$ & $5.0 \mathrm{E}-01$ & $5.0 \mathrm{E}-01$ & $5.0 \mathrm{E}-01$ \\
\hline $\mathrm{U}^{2}$ & $1.2 \mathrm{E}-03$ & $1.2 \mathrm{E}-03$ & $1.2 \mathrm{E}-03$ \\
\hline
\end{tabular}

Notes:

${ }^{1}$ Moles of inorganic carbon atoms per mole of sodium

${ }^{2}$ Moles of organic carbon atoms per mole of sodium

\section{TABLE 4.2 LOW-ACTIVITY WASTE FEED RADIONUCLIDE CONTENT MAXIMUM LIMITS, SOLUBLE FRACTION ONLY}

(Bq per mole of sodium)

\begin{tabular}{|l|c|c|c|}
\hline \multicolumn{1}{|c|}{ Radionuclide } & Envelope $A$ & Envelope B & Envelope C \\
\hline $\mathrm{TRU}^{2}$ & $4.8 \mathrm{E}+05$ & $4.8 \mathrm{E}+05$ & $3.0 \mathrm{E}+6$ \\
\hline${ }^{137} \mathrm{Cs}$ & $4.3 \mathrm{E}+09$ & $2.0 \mathrm{E}+10$ & $4.3 \mathrm{E}+09$ \\
\hline${ }^{90} \mathrm{Sr}$ & $4.4 \mathrm{E}+07$ & $4.4 \mathrm{E}+07$ & $8.0 \mathrm{E}+08$ \\
\hline${ }^{99} \mathrm{Tc}$ & $7.1 \mathrm{E}+06$ & $7.1 \mathrm{E}+06$ & $7.1 \mathrm{E}+06$ \\
\hline${ }^{60} \mathrm{Co}$ & $6.1 \mathrm{E}+04$ & $6.1 \mathrm{E}+04$ & $3.7 \mathrm{E}+05$ \\
\hline${ }^{154} \mathrm{Eu}$ plus ${ }^{155} \mathrm{Eu}$ & $1.2 \mathrm{E}+06$ & $1.2 \mathrm{E}+06$ & $4.3 \mathrm{E}+06$ \\
\hline
\end{tabular}

Notes:

\footnotetext{
${ }^{1}$ The activity limit shall apply to the feed certification date.
}

${ }^{2}$ TRU is defined in accordance with 10 CFR Part 61.55 . 
HNF-1796 Rev. 2

TABLE 4.3. INSOLUBLE COMPONENTS REQUIRING CHARACTERIZATION

\begin{tabular}{|c|c|}
\hline Chemicals & Radionuclides \\
\hline $\mathrm{Al}$ & ${ }^{90} \mathrm{Sr}$ \\
$\mathrm{Cr}$ & ${ }^{137} \mathrm{Cs}$ \\
$\mathrm{P}$ & ${ }^{60} \mathrm{Co}$ \\
$\mathrm{S}$ & ${ }^{154} \mathrm{Eu}$ \\
$\mathrm{Si}$ & ${ }^{155} \mathrm{Eu}$ \\
$\mathrm{Na}$ & Total Alpha \\
$\mathrm{TIC}$ & \\
$\mathrm{TOC}$ & \\
\hline
\end{tabular}

TABLE 4.4. APPLICABLE TANK FARM OPERATING SPECIFICATIONS (OSD-T-151-00007)

\begin{tabular}{|c|c|}
\hline Variable & \multicolumn{1}{|c|}{ Specification } \\
\hline For $\left[\mathrm{NO}_{3}\right] \leq 1.0$ molar $(\underline{\mathrm{M}})$ & $0.010 \underline{\mathrm{M}} \leq[\mathrm{OH}] \leq 5.0 \underline{\mathrm{M}}$ \\
& $0.011 \underline{\mathrm{M}} \leq[\mathrm{NO}] \leq 5.5 \underline{\mathrm{M}}$ \\
& {$\left[\mathrm{NO}_{3}\right] /[\mathrm{OH}]+\left[\mathrm{NO}_{2}\right]<2.5$} \\
\hline For $1.0 \underline{\mathrm{M}}<\left[\mathrm{NO}_{3}\right] \leq 3.0 \underline{\mathrm{M}}$ & $0.1\left[\mathrm{NO}_{3}\right] \leq[\mathrm{OH}]<10 \underline{\mathrm{M}}$ \\
& {$[\mathrm{OH}]+\left[\mathrm{NO}_{2}\right] \geq 0.4\left[\mathrm{NO}_{3}\right]$} \\
\hline For $\left[\mathrm{NO}_{3}\right]>3.0 \underline{\mathrm{M}}$ & $0.3 \underline{\mathrm{M}} \leq[\mathrm{OH}]<10 \underline{\mathrm{M}}$ \\
& {$[\mathrm{OH}]+[\mathrm{NO}] \geq 1.2 \underline{\mathrm{M}}$} \\
& {$[\mathrm{NO}] \leq 5.5 \underline{\mathrm{M}}$} \\
\hline
\end{tabular}

\subsection{INPUTS FOR WASTE TRANSFER DECISION}

Candidate LAW feed in each tank will be mixed, undissolved solids will be allowed to settle, and supernate will be transferred to the staging tank. Measurements of physical and rheological properties of the waste are needed to confirm that the waste can be effectively mixed and the supernate transferred to the Privatization Contractor. These properties are shown in Table 4.5. The associated limits were established based on an analysis of the capability of the proposed transfer routes (Galbraith et al. 1996). 
HNF-1796 Rev. 2

TABLE 4.5. WASTE TRANSFER PROPERTIES AND ASSOCIATED LIMITS

\begin{tabular}{|c|c|}
\hline Property & Maximum Limit \\
\hline & 10 centiPoise \\
Viscosity & 1.5 \\
Specific gravity & 30 \\
Volume percent solids & \\
\hline
\end{tabular}

The properties listed in Table 4.5 will be obtained by measuring sample material that has been prepared to simulate mixed and/or diluted tank waste. If the data indicate that these properties exceed the corresponding limits, process tests will be performed to determine the necessary dilution ratio (i.e., volume of diluent to that of waste). The following data will be needed to support mixing and/or dilution operations:

- The observed physical form of the raw waste (e.g., supernate, crust, saltcake, salt slurry, or metal oxide sludge),

- The fraction of solids that will be dissolved during mixing,

- The solids dissolution rate or the total amount of time required to dissolve the solids,

- The settling rate of undissolved solids, and

- Physical properties of undissolved solids (before and after mixing) for modeling waste behavior during waste transfer operations. These properties include particle size distribution and density.

Dilution may be necessary in some cases to satisfy the waste transfer or feed envelope requirements. The target dilution ratio will be estimated from existing waste composition and thermodynamic equilibrium calculations. The target dilution ratio will be confirmed through laboratory process tests and will fall within the following range:

- The minimum dilution ratio at which the diluted waste satisfies all above waste transfer requirements, and

- The maximum dilution ratio, beyond which gibbsite would form (at a temperature between $25^{\circ} \mathrm{C}$ and $65^{\circ} \mathrm{C}$ ) or based on tank space requirement.

The optimum dilution ratio would be slightly above the minimum ratio. Also, the mixing/dilution tests will confirm that major sodium salts (e.g., sodium nitrate, sodium nitrite) in the retrieved waste will remain in solution (i.e., below their saturation points). Details of mixing and/or dilution process tests will be developed and documented in laboratory test plans. 


\subsection{INPUTS FOR QUANTITY DECISION}

The TWRS Privatization Contract (Section $\mathrm{H}$ ) specifies quantity requirements for LAW feed delivery in terms of "units." A unit for each waste envelope is defined as follow:

Envelope A 1 metric ton of sodium $=1$ unit

Envelope B 1 metric ton of sodium $=2.6$ units or $\frac{X}{Y}$ units

Envelope C $\quad 1$ metric ton of sodium $=1.15$ units or $\frac{X}{Y}$ units

Where $\mathrm{X}$ is equal to 20 weight percent sodium oxide loading in the LAW glass and $Y$ is equal to the achievable waste sodium oxide loading for a particular waste feed.

The contract quantity requirements applicable to this DQO are summarized below:

- The order quantity is 6,000 units (5,600 of Envelopes A, B, C, and 400 units of previously pretreated Envelope B \{i.e., high-level waste supernate\}),

- The maximum order quantity in a given year is 1,100 units. Additional units may be granted upon request by the Privatization Contractor, and

- The maximum cumulative units of LAW that the Privatization Contractor may process by the end of each year of operation shall be:

\begin{tabular}{cr}
$\frac{\text { Year of }}{\text { Operation }}$ & Units \\
\cline { 1 - 2 } 1 & 800 \\
2 & 1,600 \\
3 & 2,400 \\
4 & 3,200 \\
5 & 4,000 \\
6 & 4,800 \\
7 & 5,600 \\
8 & 6,000 \\
9 & 6,000
\end{tabular}

To determine the number of units per batch or tank, sodium concentration and total volume of waste in the batch or tank must be known. Sodium concentration will be determined as required in Section 4.1. Total volume of waste in a given tank or batch will be determined from liquid level measurements. These measurements are performed on a routine basis as part of TWRS operations. Also, there is no quantity limit specified by the Privatization 
Contract for each batch of LAW feed. Therefore, quantity decision and requirements will no longer be considered in this DQO.

\subsection{ANALYTICAL METHODS AND QUALITY CONTROL REQUIREMENTS}

The suggested analytical methods and the quality control (QC) requirements applicable to each analysis are provided in Table 4.6. For purposes of this DQO, total alpha activity will be used as a screening analysis and conservative indicator of transuranic (TRU) content. If the total alpha activity is greater than 80 percent of the TRU envelope limit, isotopic distribution will be required.

TABLE 4.6. REQUIRED ANALYTES AND QUALITY CONTROL REQUIREMENTS (3 SHEETS).

\begin{tabular}{|c|c|c|c|c|}
\hline \multirow{2}{*}{$\begin{array}{l}\text { Analyte } \\
\text { (Measured in } \\
\text { Solids) }\end{array}$} & \multirow{2}{*}{$\begin{array}{l}\text { Analytical } \\
\text { Techinicue }\end{array}$} & \multicolumn{3}{|c|}{ QC Acceptance Criteria } \\
\hline & & $\begin{array}{l}\text { LQS } \\
\text { \%Recovery }\end{array}$ & Spilke & $\begin{array}{l}\text { Duplicate } \\
\text { RPD }^{3}\end{array}$ \\
\hline $\begin{array}{l}\text { Cations listed in } \\
\text { Tables } 4.1 \text { and } 4.3 \\
\text { (except } \mathrm{Hg} \text { ) }\end{array}$ & ICP/AES ${ }^{7,6}$ & $80-120 \%$ & $75-125 \%$ & $\leq 20 \%$ \\
\hline $\mathrm{Hg}$ & CVAA $^{7,6}$ & $80-120 \%$ & $75-125 \%$ & $\leq 20 \%$ \\
\hline $\mathrm{NO}_{2}^{-}, \mathrm{NO}_{3}^{-}, \mathrm{Cl}^{-}, \mathrm{F}^{-}$ & Ion Chromatography $^{7}$ & $80-120 \%$ & $75-125 \%$ & $\leq 20 \%$ \\
\hline $\begin{array}{l}\text { Total Inorganic } \\
\text { Carbon }\left(\mathrm{CO}_{3}\right)\end{array}$ & Persulfate & $80-120 \%$ & $75-125 \%$ & $\leq 20 \%$ \\
\hline TOC & $\begin{array}{l}\text { Silver catalyzed } \\
\text { persulfate and } \\
\text { combustion furnace }^{7}\end{array}$ & $80-120 \%$ & $75-125 \%$ & $\leq 20 \%$ \\
\hline Wt $\%$ solids & Gravimetric & $80-120 \%$ & N/A & $\leq 30 \%$ \\
\hline $\mathrm{OH}$ & $\begin{array}{l}\text { Potentiometric } \\
\text { titration }\end{array}$ & $80-120 \%$ & $\mathrm{~N} / \mathrm{A}$ & $\leq 20 \%$ \\
\hline Slurry density & & N/A & $\mathrm{N} / \mathrm{A}$ & N/A \\
\hline $\begin{array}{l}\text { Volume \% settled } \\
\text { solids }\end{array}$ & Visual & N/A & N/A & N/A \\
\hline${ }^{60} \mathrm{Co}$ & GEA & $80-120 \%$ & N/A ${ }^{5}$ & $\leq 20 \%$ \\
\hline${ }^{99} \mathrm{Tc}$ & Liquid scintillation & $80-120 \%$ & $70-130 \%$ & $\leq 20 \%$ \\
\hline${ }^{90} \mathrm{Sr}$ & $\begin{array}{l}\text { Isotopic specific } \\
\text { separation/beta count }\end{array}$ & $75-125 \%$ & $N / A^{4}$ & $\leq 20 \%$ \\
\hline
\end{tabular}


TABLE 4.6. REQUIRED ANALYTES AND QUALITY CONTROL REQUIREMENTS (3 SHEETS).

\begin{tabular}{|c|c|c|c|c|}
\hline \multirow{2}{*}{$\begin{array}{l}\text { Analyte } \\
\text { (Measured in } \\
\text { Solids) }\end{array}$} & \multirow{2}{*}{ Analy treal } & \multicolumn{3}{|c|}{ QC Acceptance Oriteria } \\
\hline & & \% $\%$ Rerovery & $\begin{array}{l}\text { Spike } \\
\text { \%orecovery }\end{array}$ & $\begin{array}{l}\text { Duplicate } \\
\text { RPD }\end{array}$ \\
\hline${ }^{137} \mathrm{Cs}$ & GEA & NP & $N / A^{5}$ & $\leq 20 \%$ \\
\hline${ }^{154} \mathrm{Eu}$ & GEA & NP & N/A ${ }^{5}$ & $\leq 20 \%$ \\
\hline${ }^{155} \mathrm{Eu}$ & GEA & NP & N/A ${ }^{5}$ & $\leq 20 \%$ \\
\hline Total Alpha & Proportional counter & $70-130 \%$ & $70-130 \%$ & $\leq 20 \%$ \\
\hline
\end{tabular}

Notes:

AEA = Alpha energy analysis

CVAA = cold vapor atomic absorption

GEA = gamma emission analysis

ICP/AES = Inductively coupled plasma/atomic emission spectroscopy

$\mathrm{ICP} / \mathrm{MS}=\mathrm{ICP} /$ mass spectrometry

$\mathrm{N} / \mathrm{A} \quad=$ Not applicable

$\mathrm{NP} \quad=$ Not performed

TOC $=$ total organic carbon

'LCS = Laboratory Control Standard. This standard is carried through the entire method. The accuracy of a method is usually expressed as the percent recovery of the LCS. The LCS is a matrix with known concentration of analytes processed with each preparation and analyses batch. It is expressed as percent recovery; i.e., the amount measured, divided by the known concentration, times 100 .

${ }^{2}$ For some methods, the sample accuracy is expressed as the percent recovery of a matrix spike (MS) sample. It is expressed as percent recovery; i.e., the amount measured, less the amount in the sample, divided by the spike added, times 100 . One matrix spike is performed per analytical batch. Samples are batched according to matrix similarity.

${ }^{3} \mathrm{RPD}=$ Relative Percent Difference between the sample and duplicate results. Duplicates will be taken through preparation and analysis. Instrument analysis duplicates cannot be substituted except GEA which requires no preparation. Sample precision is estimated by analyzing duplicates. Acceptable sample precision is usually $<20$ percent RPD if the sample result is at least 10 times the instrument detection limit.

$\mathrm{RPD}=(\mid$ Result $1-$ Result $2 \mid$ /average result $) \times 100$.

${ }^{4} \mathrm{MS}$ analyses are not required for this method because a tracer or carrier is used to correct for analyte loss during sample preparation and analysis. The result generated using the tracer accounts for an inaccuracy of the method on the matrix. The reported results reflect this correction.

${ }^{5}$ The measurement is a direct reading of the energy and the analysis is not affected by the sample matrix; therefore, an MS is not required.

${ }^{6}$ All samples must be digested using the appropriate method prior to metals analyses.

${ }^{7}$ This method or other comparable method should be used. 
The minimum reportable quantities (MRQs) for LAW feed chemical and radionuclide analyses (See Tables 4.7 and 4.8) are specified in the interface control document for LAW feed (PHMC 1997). These values are considered to be minimum requirements for selected constituents in the LAW feed samples. The estimated quantitation limit (EQL) and minimum detectable activity (MDA) have been corrected for dilution associated with sample preparation. Measurements less than the EQL/MDA will be reported as " $<$ " the EQL/MDA. The minimum reportable quantities (also called practical quantitation quantities) are, in general, a factor of three greater than the EQL/MDA. Measurements between the EQL/MDA and MRQ values will be reported as absolute values; however, the analytical error associated with these data may be large relative to data greater than the MRQ.

TABLE 4.7. MINIMUM REPORTABLE QUANTITIES FOR LAW FEED, SOLUBLE FRACTION ONLY (2 SHEETS)

\begin{tabular}{|c|c|c|}
\hline Analyte & $\begin{array}{c}\text { Estimated Quantitation Limits } \\
\text { (EQL) } \\
\mu \mathrm{g} / \mathrm{mL}, \mu \mathrm{Ci} / \mathrm{mL}\end{array}$ & $\begin{array}{c}\text { Minimum Reportable Quantity } \\
\text { (MRQ) } \\
\mu \mathrm{g} / \mathrm{mL}, \mu \mathrm{Ci} / \mathrm{mL}\end{array}$ \\
\hline$\overline{\mathrm{Al}}$ & $2.5 \mathrm{E}+01$ & $7.5 \mathrm{E}+01$ \\
\hline $\mathrm{Ba}$ & $2.6 \mathrm{E}+01$ & $7.8 \mathrm{E}+01$ \\
\hline $\mathrm{Ca}$ & $5.0 \mathrm{E}+01$ & $1.5 \mathrm{E}+02$ \\
\hline $\mathrm{Cd}$ & $2.5 \mathrm{E}+00$ & $7.5 \mathrm{E}+00$ \\
\hline $\mathrm{Cl}^{-}$ & $1.0 \mathrm{E}+02$ & $3.0 \mathrm{E}+00$ \\
\hline $\mathrm{Cr}$ & $5.0 \mathrm{E}+00$ & $1.5 \mathrm{E}+01$ \\
\hline $\mathrm{F}^{-}$ & $5.0 \mathrm{E}+01$ & $1.5 \mathrm{E}+02$ \\
\hline $\mathrm{Fe}$ & $2.5 \mathrm{E}+01$ & $7.5 E+01$ \\
\hline $\mathrm{Hg}$ & $5.0 \mathrm{E}-01$ & $2.0 \mathrm{E}+00$ \\
\hline $\mathrm{K}$ & $2.5 \mathrm{E}+02$ & $7.5 \mathrm{E}+01$ \\
\hline $\mathrm{La}$ & $2.5 \mathrm{E}+01$ & $3.5 \mathrm{E}+01$ \\
\hline $\mathrm{Ni}$ & $1.0 \mathrm{E}+01$ & $3.0 \mathrm{E}+01$ \\
\hline $\mathrm{NO}_{2}^{-}$ & $7.5 \mathrm{E}+02$ & $2.3 \bar{E}+03$ \\
\hline $\mathrm{NO}_{3}^{-}$ & $1.0 \mathrm{E}+03$ & $3.0 \mathrm{E}+03$ \\
\hline $\mathrm{Pb}$ & $9.9 \mathrm{E}+-1$ & $3.0 \mathrm{E}+02$ \\
\hline $\mathrm{PO}_{4}^{-2}$ & $7.5 \mathrm{E}+02$ & $2.5 \mathrm{E}+03$ \\
\hline $\mathrm{SO}_{4}^{-2}$ & $7.7 \mathrm{E}+02$ & $2.3 \mathrm{E}+03$ \\
\hline TIC & $5.0 \mathrm{E}+01$ & $1.5 E+02$ \\
\hline TOC & $5.0 \mathrm{E}+02$ & $1.5 \mathrm{E}+03$ \\
\hline $\mathrm{U}$ & $2.0 \mathrm{E}-01$ & $6.0 \mathrm{E}+02$ \\
\hline $\mathrm{TRU}^{\mathrm{T}}$ & & \\
\hline $\mathrm{Pu}^{238,239,240,241,242}$ & $3.20 \mathrm{E}-03$ for each isotope & \multirow{5}{*}{$\begin{array}{c}3 \text { times the detection limit for } \\
\text { each isotope }\end{array}$} \\
\hline $\mathrm{Np}^{237}$ & $9.1 \mathrm{E}-03$ & \\
\hline $\mathrm{Cm}^{243,244}$ & $5.0 \mathrm{E}-02$ & \\
\hline $\mathrm{Am}^{241}$ & $2.4 \mathrm{E}-04$ & \\
\hline $\mathrm{Am}^{243}$ & $3.2 \mathrm{E}-03$ & \\
\hline
\end{tabular}


HNF-1796 Rev. 2

TABLE 4.7. MINIMUM REPORTABLE QUANTITIES FOR LAW FEED, SOIUBLE FRACTION ONLY (2 SHEETS)

\begin{tabular}{|c|c|c|}
\hline Analyte & $\begin{array}{c}\text { Estimated Quantitation Limits } \\
(\mathbf{E Q L}) \\
\mu \mathrm{g} / \mathbf{m L}, \mu \mathbf{C i} / \mathbf{m L}\end{array}$ & $\begin{array}{c}\text { Minimum Reportable Quantity } \\
\text { (MRQ) } \\
\mu \mathrm{g} / \mathbf{m L}, \mu \mathbf{C i} / \mathbf{m L}\end{array}$ \\
\hline $7{ }^{60} \mathrm{Co}$ & $7.0 \mathrm{E}-04$ & 2.1 \\
\hline${ }^{90} \mathrm{Sr}$ & $5.0 \mathrm{E}-02$ & 1.5 \\
\hline${ }^{99} \mathrm{Tc}-03$ \\
\hline${ }^{137} \mathrm{Es}$ & $5.0 \mathrm{E}-04$ & 1.5 \\
\hline${ }^{154} \mathrm{E}-03$ \\
\hline${ }^{155} \mathrm{Eu}$ & $3.0 \mathrm{E}+00$ & 9.0 \\
$\mathrm{E}+00$ \\
\hline
\end{tabular}

${ }^{1}$ The sum of the detection limits for the TRU components is greater than the Specification 7, Envelopes A, B, and $C$ limits. 
HNF-1796 Rev. 2

TABLE 4.8. MINIMUM REPORTABLE QUANTITIES FOR LAW FEED ANALYTES NOT SPECIFIED IN FEED ENVELOPE, SOLUBLE FRACTION ONLY

\begin{tabular}{|c|c|c|}
\hline Analyte & $\begin{array}{c}\text { Minimum Detectable Activity } \\
\text { (MDA) } \\
\mu \mathrm{g} / \mathrm{mL}, \mu \mathrm{Ci} / \mathrm{mL} \\
\end{array}$ & $\begin{array}{c}\text { Minimum Reportable Quantity } \\
\text { (MRQ) } \\
\mu \mathrm{g} / \mathbf{m L}, \mu \mathrm{Ci} / \mathbf{m L} \\
\end{array}$ \\
\hline $\overrightarrow{\mathrm{Ag}}$ & $5.5 \mathrm{E}+00$ & $1.75 \mathrm{E}+01$ \\
\hline As & $1.0 \mathrm{E}+00$ & $3.0 \mathrm{E}+00$ \\
\hline $\mathrm{Be}$ & $3.0 \mathrm{E}+00$ & $9.9 \mathrm{E}+00$ \\
\hline $\mathrm{Co}$ & $1.0 \mathrm{E}-01$ & $3.0 \mathrm{E}+01$ \\
\hline $\mathrm{Cu}$ & $5 . \overline{\mathrm{E}+00}$ & $1.7 \mathrm{E}+01$ \\
\hline $\mathrm{Fe}$ & $3.0 \mathrm{E}+01$ & $9.9 \mathrm{E}+01$ \\
\hline $\mathrm{Mg}$ & $5.0 \mathrm{E}+01$ & $1.5 \mathrm{E}+02$ \\
\hline Mo & $3.0 \mathrm{E}+01$ & $9.0 \mathrm{E}+01$ \\
\hline $\mathrm{NH}_{4} / \mathrm{NH}_{3}$ & $4.5 \mathrm{E}+01$ & $1.4 \mathrm{E}+02$ \\
\hline$P$ & $1.1 \mathrm{E}+02$ & $3.3 \mathrm{E}+02$ \\
\hline $\mathrm{Pt}$ & $6.0 \mathrm{E}-01$ & $1.8 \mathrm{E}+00$ \\
\hline $\mathrm{S}$ & $5.5 \mathrm{E}+01$ & $1.7 \mathrm{E}+02$ \\
\hline $\mathrm{Sb}$ & $3.5 \mathrm{E}+01$ & $1.0 \mathrm{E}+02$ \\
\hline $\mathrm{Se}$ & $5.5 \mathrm{E}+01$ & $1.7 \mathrm{E}+-2$ \\
\hline $\mathrm{Sn}$ & $5.0 \mathrm{E}+02$ & $1.5 \mathrm{E}+03$ \\
\hline $\mathrm{Ti}$ & $5.5 \mathrm{E}+00$ & $1.7 \mathrm{E}+01$ \\
\hline Total Alpha & $7.5 \mathrm{E}-02$ & $2.3 \mathrm{E}-01$ \\
\hline $\mathrm{V}$ & $3.0 \mathrm{E}+01$ & $9.0 \mathrm{E}+01$ \\
\hline $\mathrm{Y}$ & $1.0 \mathrm{E}+02$ & $2.0 \mathrm{E}+02$ \\
\hline $\mathrm{Zn}$ & $5.5 \mathrm{E}+00$ & $1.65 \mathrm{E}+01$ \\
\hline $\mathrm{Zr}$ & $5.5 \mathrm{E}+00$ & $1.65 \mathrm{E}+01$ \\
\hline $\mathrm{H}^{3}$ & $7.0 \mathrm{E}-03$ & $2.1 \mathrm{E}-02$ \\
\hline $\mathrm{C}^{14}$ & $2.4 \mathrm{E}-04$ & $7.2 \mathrm{E}-04$ \\
\hline $\mathrm{Sb}^{125}$ & $5.6 \mathrm{E}-01$ & $1.7 \mathrm{E}+00$ \\
\hline $\mathrm{Sn}^{126}$ & $2.0 \mathrm{E}-03$ & $6.0 \mathrm{E}-03$ \\
\hline$I^{129}$ & $3.5 \mathrm{E}-04$ & $1.1 \mathrm{E}-03$ \\
\hline $\mathrm{U}^{233}$ & $6.0 \mathrm{E}-04$ & $1.8 \mathrm{E}-03$ \\
\hline $\mathrm{U}^{234}$ & $4.0 \mathrm{E}-08$ & $1.2 \mathrm{E}-07$ \\
\hline $\mathrm{U}^{235}$ & $1.1 \mathrm{E}-06$ & $3.3 \mathrm{E}-06$ \\
\hline $\mathrm{U}^{238}$ & $1.7 \mathrm{E}-07$ & $5.0 \mathrm{E}-07$ \\
\hline
\end{tabular}




\subsection{DEFINE THE STUDY BOUNDARIES}

Characteristics of candidate LAW feed and HLW liquid will be estimated from waste analyses and laboratory tests that simulate feed delivery operations and conditions. Physical, chemical, radiological, and rheological properties of the waste will be determined, as needed, in a timely manner to support feed delivery decisions. Data will be obtained for each tank before waste transfer; thus, the decisions based on these data are applicable only to individual tanks or batches.

Physical and chemical characteristics of the LAW feeds are not expected to change much over a number of years (provided that storage conditions remain the same). Radionuclide concentrations in the wastes will decrease because of radioactive decay but the data can accurately be adjusted by decay calculations. Therefore, data collected with this DQO are expected to be applicable throughout the projected schedule for waste feed delivery and treatment.

Two constraints will likely be encountered during collection of the LAW data. First, the double-shell tanks in which the wastes are stored were designed with limited access to the interior of the tanks (i.e., the number of risers). In some cases, the number and locations of samples will be predetermined by the tank configurations. Secondly, the cost of laboratory analysis for these samples will be high because of precautions necessary when dealing with radioactive materials. These constraints will be considered when a sampling design is developed for each tank. 


\subsection{DEVELOP A DECISION RULE}

To resolve the principal study questions, the statistical parameter of interest is the true mean of a waste property in a given feed batch or tank. The decision rules for this DQO can be stated as follows:

- If the true unknown means of chemical and radiological concentrations of LAW feed in Tank $\mathrm{T}$ are less than or equal to the maximum feed envelope requirements (or greater than or equal to the minimum limits), then these requirements are considered satisfied. Otherwise, negotiations for accepting out-of-specification feed must be conducted or another waste source must be selected.

- If the true unknown means of physical and rheological properties of the LAW feed are less than or equal to the waste transfer limits, then these requirements are considered satisfied. Otherwise, actions must be taken to modify the waste characteristics, to select another waste, or to modify the limits.

If the true unknown means of all interested properties are less than or equal to the corresponding upper limits (or greater than or equal to the lower limits), then "Tank $T$ is confirmed as an appropriate feed source for $L A W$ Feed Batch $X$." The true unknown mean of a given property is considered less than or equal to the requirement if the upper limit to a one-sided confidence interval (i.e., the upper confidence level) is less than the requirement. The probability associated with the confidence interval for each property is specified in Section 7.0 . 


\subsection{SPECIFY TOLERABLE LIMITS ON DECISION ERRORS}

Low-activity wastes in Phase I candidate feed tanks were generated from different operations at many site facilities (e.g., PUREX, Tank Farms, B Plant, Z Plant, laboratories, etc.). Also, the wastes were commingled in different combinations. It is expected that waste properties vary significantly from tank to tank. Variation in properties within a given tank would be smaller. Variations in properties of candidate waste feed indicate the possibility of a significant decision error. For this reason, acceptable error levels for each decision (feed envelope and waste transfer) are established in Sections 7.1 and 7.2.

\subsection{ACCEPTABLE ERRORS FOR FEED ENVELOPE DECISION}

The null hypothesis $\left(\mathrm{H}_{0}\right)$ for the feed envelope decision is that the chemical and radionuclide concentrations are outside the feed envelope limits, and the alternative hypothesis $\left(\mathrm{H}_{\mathrm{a}}\right)$ is that the concentrations are within the limits. The null hypothesis presumes that the stated condition (i.e., waste concentrations exceed limits) is true in the absence of strong evidence to the contrary. Selection of the null hypothesis in this way provides a guard against concluding that LAW in Tank T satisfies the envelope limits when it does not. The hypotheses can be restated as follows:

$$
\begin{array}{ll}
\mathrm{H}_{\mathrm{o}}: \mathrm{R}>\mathrm{Upper} \text { Limit } & \text { (for sodium, } \mu<3 \underline{\mathrm{M}} \text { or } \mu>10 \underline{\mathrm{M}} \text { ) } \\
\mathrm{H}_{\mathrm{a}}: \mathrm{R} \leq \text { Upper Limit } & \text { (for sodium, } 3 \underline{\mathrm{M}} \leq \mu \leq 10 \underline{\mathrm{M}} \text { ) }
\end{array}
$$

Where: $\mu$ is the true unknown mean of a waste property (i.e., sodium concentration) and $\mathrm{R}$ is the true unknown ratio of means (mean moles or mean $\mathrm{Bq}$ of component per mean mole of sodium).

The decision errors associated with the null and alternative hypotheses are as follows:

Type I Error (false positive): The data indicate that the properties are within the feed envelope when they are truly outside the envelope limits.

Type II Error (false negative): The data indicate that the properties are outside the envelope limits when they truly are within the envelope.

Potential consequences of the Type I error include:

- The waste could be transferred to the staging tank where the error is found via certification sampling. DOE would have to negotiate with the Privatization Contractor to accept out-of-specification feed. Negotiations conducted at that time may result in significant project delay. 


\section{HNF-1796 Rev. 2}

- The error is found after treatment of LAW results in out-of-specification product. Resolution of the error may result in significant cost overrun and schedule delay.

- The error is never found. The treatment process is sufficiently robust to process slightly out-of-specification feed into acceptable product.

Potential consequences of the Type II error include:

- The waste could be transferred to the staging tank where the error is found. By then, negotiation for acceptance of out-of-specification feed would have taken place. Negotiation effort would be unnecessary but processing schedule would not be affected.

- The error is never found. DOE would have conducted unnecessary negotiation with the Privatization Contractor and possibly paid additional costs to the contractor for treating what was thought to be out-of-specification feed.

Overall, the consequences of the Type I error could be very high. Hence, the tolerable limit, alpha ( $\alpha$ ), is set at 0.05 (for a one-sided $95 \%$ confidence level) to guard against this type of error. The potential consequences for Type II error are slightly lower, thus the corresponding tolerable limit, beta $(\beta)$, is set at 0.1 .

\subsection{ACCEPTABLE ERROR LIMITS FOR WASTE TRANSFER DECISION}

The null hypothesis $\left(\mathrm{H}_{0}\right)$ for the waste transfer decision is that the physical properties exceed the waste transfer limits, and the alternative hypothesis $\left(\mathrm{H}_{\mathrm{a}}\right)$ is that the properties are under the limits. The null hypothesis presumes that the stated condition (i.e., waste properties exceed limits) is true in the absence of strong evidence to the contrary. Selection of the null hypothesis in this way provides a guard against concluding that LAW in Tank T satisfies waste transfer limits when it does not. The hypotheses can be restated as follows:

$\mathrm{H}_{\mathrm{o}}: \mu>$ Upper Limit

$\mathrm{H}_{\mathrm{a}}: \mu \leq \mathrm{Upper}$ Limit

Where $\mu$ is the true unknown mean of a waste property.

The decision errors associated with the null and alternative hypotheses are as follows:

Type I Error (false positive): The data indicate that the properties are below the waste transfer limits when they are truly above the limits.

Type II Error (false negative): The data indicate that the properties are above the limits when they truly are below. 
Potential consequences of the Type I error: The error is discovered during waste transfer to a staging tank. Waste transfer operations could be delayed to conduct engineering evaluation or additional process testing. Feed delivery schedule may be adversely affected.

Potential consequence of the Type II error: Waste properties may be modified unnecessarily.

The consequences of these types of decision errors could be significant. A tolerable limit of 0.1 is set for both alpha and beta (for a one-sided $90 \%$ confidence level). 


\subsection{OPTIMIZE THE DESIGN FOR DATA COLLECTION}

Data will be collected for LAW in a number of tanks under the direction provided in this DQO. The characteristics and storage conditions of waste in each tank are unique. Also, the quantity and quality of existing data for waste in these tanks are different. For these reasons, a sampling design applicable for all LAW feed tanks is not possible. Rather, direction for designing a sample scheme that satisfies the data needs for each tank is provided. Optimized sampling designs will be developed for individual tanks based on this DQO and will be documented in tank-specific sampling and analysis plans (SAPs).

The type and quantity of data required to support each DQO decision are different. The number of samples will be determined separately for each decision. The total number of samples taken from each tank would be the highest calculated value. However, not all required analyses and tests will be performed on every sample. Direction for determining the right quantity of data to address each $\mathrm{DQO}$ decision is provided in the next two sections.

\subsection{OPTIMIZE SAMPLING DESIGN FOR FEED ENVELOPE DECISION}

The number of samples needed to support the feed envelope decision, $\mathrm{n}_{1}$, will be calculated using the following equation (EPA 1994):

$$
n_{1}=\frac{\sigma^{2}\left(Z_{1-b}+Z_{1-\alpha}\right)^{2}}{\Delta^{2}}+0.5 Z_{1-\alpha}^{2}
$$

where:

$$
\begin{aligned}
& \mathrm{n}_{1}=\text { minimum number of samples required } \\
& \sigma^{2}=\text { estimated variance in measurements } \\
& \mathrm{Z}=\text { quantile of the standard normal distribution (from standard } \\
& \text { statistical table) } \\
& \Delta=\text { difference between the action level and the estimated mean. }
\end{aligned}
$$

As discussed in the Decision Rule, action levels are the feed envelope limits. The mean concentrations for the feed envelope properties can be estimated from existing analytical data and results of previous waste mixing and/or dilution tests.

The variance for each parameter would be calculated if sufficient data are available. If data are insufficient, the variance (or standard deviation) can be estimated based on analytical results for a similar tank or based on the expected degree of mixing prior to and during waste transfer. The acceptable error levels specified in Section 7.1 will be used to obtain the appropriate $Z$ values from a standard statistical table. Using this method, $n_{1}$ can be calculated for all feed envelope properties. The largest value calculated for $n_{1}$ is the minimum number of samples that must be taken to allow the decision to be made in 


\section{HNF-1796 Rev. 2}

accordance with the established rule. Additional samples may be obtained for contingency purpose.

Variability in tank waste such as different phases and layers, if it exists, shall be addressed by the sampling scheme so that analytical results may be used to describe the whole content of the tank. Each sample must contain sufficient material to perform the required mixing (and dilution if necessary) process tests. Laboratory process tests will provide the following information:

- Fraction of solids that dissolve during mixing,

- Solids dissolution rate (or total dissolution time),

- Solids settling rate after mixing,

- Physical properties of undissolved solids (before and after mixing) including particle size and density,

- Confirmation that sodium salts remain in solution,

- Visual inspection for a separate organic layer, and

- Target dilution ratio (only if dilution is necessary).

Soluble fractions from the $n_{1}$ samples will be observed for a separate organic layer and analyzed for sodium, hydroxide, weight percent solids, and components listed in Tables 4.1 and 4.2 of this DQO. The undissolved solids will then be analyzed for components listed in Table 4.3 .

\subsection{OPTIMIZE SAMPLING DESIGN FOR THE WASTE TRANSFER DECISION}

The number of samples needed to support this decision, $\mathrm{n}_{2}$, will be calculated using a method similar to that described in Section 8.1. The action levels and the acceptable error levels are specified in Table 4.5 and Section 7.2, respectively. If one or more action levels were exceeded, process tests would be performed to determine the target dilution necessary to bring the waste characteristics within the acceptable criteria. The samples would be diluted at the target dilution ratio, mixed, and the properties re-measured. 


\section{HNF-1796 Rev. 2}

\subsection{SUMMARY}

A DQO process was conducted to assure appropriate data would be collected to confirm LAW in Tank $T$ is an acceptable feed source for the Privatization Contractor. The DQO identified two decision statements that require data to resolve:

- Determine whether or not LAW feed composition exceeds the envelope limits specified in the TWRS Privatization contract.

- Determine whether or not physical and rheological properties of the waste exceed established waste transfer criteria.

These decisions will be addressed for individual tanks because waste characteristics and storage conditions are unique for each tank. Also, quantity and quality of existing data for wastes in these tanks are different. For these reasons, an optimized sampling design for each LAW feed tank is needed. Direction for optimizing tank-specific sampling design is provided in Section 8.0. The number of samples $\left(n_{1}\right.$ or $\left.n_{2}\right)$ that would be required for each decision regarding a given LAW tank will be calculated as described in Sections 8.1 and 8.2. The largest value (plus a contingency) is the number of samples that would be taken from the tank. The samples shall be collected using methods appropriate to the waste media in a tank.

Material from at least two samples will be used to study waste behavior during mixing. Also, if dilution were necessary to bring the LAW feed to within acceptable transfer criteria, then dilution process tests would be needed. A target dilution ratio would be determined for the waste.

All samples collected will be mixed and diluted, if necessary, at the target dilution ratio. Soluble fraction from each of the $n_{1}$ samples will be analyzed for sodium, hydroxide, weight percent solids, and components listed in Tables 4.1 and 4.2. Undissolved solids will be analyzed for components listed in Table 4.3. Physical properties (see Table 4.5) of the sample mixture from each of the $n_{2}$ samples will be measured. The overall test and analysis scheme is summarized in Table 9.1. Many of these tests can be combined to minimize laboratory cost. Also, existing information may already be sufficient to address a number of these data requirements. Optimization of the tests/analyses including deviations (omissions or additions) from the DQO requirements will be documented in tank-specific sampling and analysis plans and/or process test plan.

It should be noted that the DQO process is meant to be iterative. Data collected will be evaluated to determine if the decision rule is satisfied. Samples collected for contingency purpose may have to be analyzed as needed. 
TABLE 9.1. OVERALL DATA COLLECTION SCHEME

\begin{tabular}{|c|c|c|}
\hline Input Requirements & $\begin{array}{c}\text { Process Tests To Prepare } \\
\text { Samples for Analysis }\end{array}$ & $\begin{array}{c}\text { Quantity of Data } \\
\text { Required }\end{array}$ \\
\hline $\begin{array}{l}\text { Observed physical form of the raw waste } \\
\text { (e.g., supernate, salt cake, salt slurry, metal } \\
\text { oxide sludge, etc.) }\end{array}$ & None & All samples \\
\hline $\begin{array}{l}\text { Fraction of solids that dissolve during } \\
\text { mixing } \\
\text { - Solids dissolution rate (or total } \\
\text { dissolution time) } \\
\text { - Solids settling rate after mixing } \\
\text { - Physical properties of undissolved } \\
\text { solids (before and after mixing) } \\
\text { including particle size and density } \\
\text { - Confirmation that sodium salts remain } \\
\text { in solution } \\
\text { Visual inspection for a separate organic } \\
\text { layer }\end{array}$ & $\begin{array}{l}\text { Mixing (Samples will be } \\
\text { mixed simulating tank mixing } \\
\text { prior to transfer) }\end{array}$ & \multirow[t]{2}{*}{$\begin{array}{l}\text { A minimum of } 2 \\
\text { measurements }\end{array}$} \\
\hline $\begin{array}{l}\text { If dilution is necessary, then dilution and } \\
\text { mixing tests (instead of the mixing tests } \\
\text { described above) will be conducted and the } \\
\text { data need includes: } \\
\text { - The six input requirements above } \\
\text { - Target dilution ratio }\end{array}$ & $\begin{array}{l}\text { Dilution (If necessary): } \\
\begin{array}{l}\text { Samples will be } \\
\text { diluted and mixed. }\end{array}\end{array}$ & \\
\hline $\begin{array}{l}\text { Soluble fraction will be analyzed for } \\
\text { feed envelope components listed in } \\
\text { Tables } 4.1 \text { and } 4.2 \text {, hydroxide, sodium, } \\
\text { and weight percent solids. } \\
\text { - Soluble fraction will be observed for a } \\
\text { visible organic phase. } \\
\text { - Undissolved solids will be analyzed for } \\
\text { components listed in Table } 4.3\end{array}$ & $\begin{array}{l}\text { Mixing (or dilution at target } \\
\text { ratio and mixing, if } \\
\text { necessary) }\end{array}$ & $\mathrm{n}_{1}$ measurements ${ }^{2}$ \\
\hline $\begin{array}{l}\text { Waste mixture containing both liquid and } \\
\text { solids will be analyzed for properties listed } \\
\text { in Table } 4.5\end{array}$ & $\begin{array}{l}\text { Mixing (or dilution at target } \\
\text { ratio and mixing, if } \\
\text { necessary) }\end{array}$ & $\mathrm{n}_{2}$ measurements ${ }^{2}$ \\
\hline
\end{tabular}

${ }^{1}$ At this time, there are no acceptance limits (or action levels) associated with mixing or dilution properties, thus the number of samples for these properties cannot be calculated. These properties will be measured from at least 2 samples to allow statistical analysis of the data.

${ }^{2}$ Each measurement shall come from a separate original tank waste sample. 


\subsection{REFERENCES}

Banning, D. L., 1997, TWRS Administrative Manual, HNF-IP-0842, Volume IV, "Engineering," Section 4.16, Rev. 0, "Data Quality Objectives for Sampling and Analyses," Lockheed Martin Hanford Corporation, Richland, Washington.

DOE-RL, 1996, TWRS Privatization, Contract Number DE-AC06-96RL13308, U. S. Department of Energy, Richland, Washington.

EPA, 1994 Guidance for the Data Quality Objectives Process, EPA QA/G-4, U. S. Environmental Protection Agency, Washington, District of Columbia.

Galbraith, J. D., T. B. Salzano, and J. R. Nicholson, 1996, Decision Document for Phase I Privatization Transfer System Needs, WHC-SD-WM-TI-750, Rev. 0, Westinghouse Hanford Company, Richland, Washington.

Kirkbride, R. A., G. K. Allen, P. J. Certa, A. F. Manuel, R. M. Orme, L. W. Shelton, E. J. Slaathaug, R. S. Wittman, G. T. MacLean, and D. L. Penwell, 1997, Tank Waste Remediation Operation and Utilization Plan, HNF-SD-WM-SP-012, Rev. 0A, Vol. I and II, Numatec Hanford Corporation, Richland, Washington.

Nguyen, D. M., 1999, Data Quality Objectives for TWRS Privatization Phase I: Confirm Tank T Is an Appropriate Feed Source for High-Level Waste Feed Batch X, HNF1558, Rev. 1, Lockheed Martin Hanford Corporation, Richland, Washington.

Payne, M. A., J. O. Honeyman, J. G. Kristofzski, W. T. Thompson, and P. J. Certa, 1998, Management Assessment of Tank Waste Remediation System Contractor Readiness to Proceed with Phase IB Privatization, HNF-2021, Rev. 1, Lockheed Martin Hanford Corporation, Richland, Washington.

PHMC, 1997, Interface Control Document Between DOE and PHMC, Low-Activity Waste Feed, HNF-SP-1224 (ICD-19), Project Hanford Management Contractor, Richland, Washington.

PHMC, 1998, Unclassified Operating Specifications for the 241-AN,AP,AW,AY,AZ, and SY Tank Farms, OSD-T-151-00007, Rev. H-21, Fluor Daniel Hanford, Richland, Washington. 


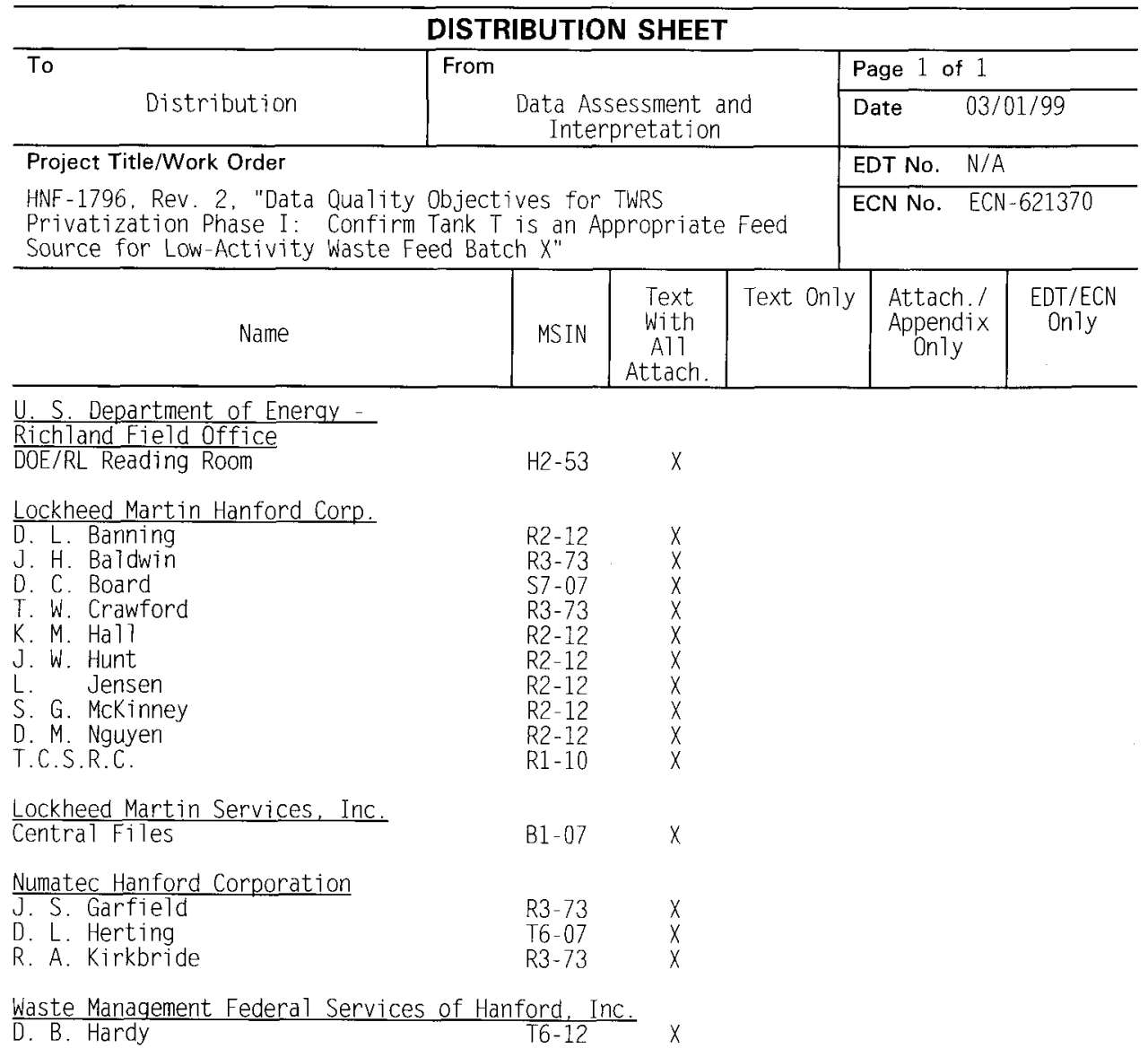

